PERSPECTIVE

\title{
The Halifax disaster (1917): eye injuries and their care
}

\author{
Chryssa N McAlister, T Jock Murray, Hesham Lakosha, Charles E Maxner
}

Br J Ophthalmol 2007;91:832-835. doi: 10.1136/bjo.2006.113878

Explosions, man-made and accidental, continue to require improved emergency medical responses. In the 1917 Halifax Explosion, an inordinate number of penetrating eye injuries occurred. A review of their treatment provides insight into a traumatic event with unique ophthalmological importance. Archived personal and government documents relating to the Halifax Explosion were reviewed at the Public Archives of Nova Scotia, Canada, along with a review of current literature. Twelve ophthalmologists treated 592 people with eye injuries and performed 249 enucleations. Sixteen people had both eyes enucleated. Most of the eye injuries were caused by shards of shattered glass. A Blind Relief Fund was established to help treat and rehabilitate the visually impaired. The injured were given pensions through the Canadian National Institute for the Blind, Toronto, Ontario, Canada, which continue to this day. Sympathetic ophthalmia was the feared complication for penetrating eye injuries and a common indication for enucleation in 1917. Even so, the severity and the overwhelming number of eye injuries sustained during the Halifax Explosion made it impossible for lengthy eye-saving procedures to be performed. Enucleation was often the only option.

See end of article for authors' affiliations

Correspondence to: Dr C Maxner, Room 3819, Halifax Infirmary, Queen Elizabeth II Health Sciences Centre, 1796 Summer Street, Halifax, Nova Scotia, Canada B3H 3A7; cmaxner@dal.ca

Accepted 4 January 2007 .................... www.bjophthalmol.com refitted and supplied before sailing in convoys to Europe. For this reason, Halifax was a prime target for the Germans, and many believed that they had attacked. ${ }^{4}$ However, the explosion was caused by an accidental collision between two vessels.

At 08:48 h, a French freighter, the Mont Blanc, collided with the Imo, a Belgian relief ship, as a result of navigational error in the Halifax Harbour. The Mont Blanc carried 3121 tons of picric acid, 200 tons of trinitrotoluene, 35 tons of benzol and 10 tons of gun cotton. ${ }^{5}$ The benzol drums ignited, with flames and smoke rising 2000 feet into the sky (fig 1). Women and men went to their windows, and children walking to school stopped on the street to watch the blazing fire. After 17 min the ship blew up with a force that launched the 6880627 pound hull over 1000 feet into the air, destroying everything within a $2.5 \mathrm{~km}$ radius and shattering every window in the city (fig 2). ${ }^{5}$

\section{RESPONSE}

Halifax had four public hospitals, one private hospital and several military hospitals, each with a few hundred beds. ${ }^{6}$ Cox walked from the train to the Camp Hill Hospital, a private veterans' hospital with 250 beds, and found over 1500 men, women and children lining the corridors. ${ }^{2}$ He first worked at a kitchen table setting bones and repairing wounds, but quickly realised that the large number of eye cases required his expertise. ${ }^{2}$ Among the local physicians who responded immediately were four other EENT specialists: EA Kirkpatrick, EA Mathers, AE Doull and AR Cunningham. ${ }^{6}$ With the assistance of a sergeant, a nursing sister and an anaesthetist, Cox started operating and did not stop for several days. ${ }^{2}$

"Pieces of glass were driven clear thro' the eye ball," he wrote, "and one found it was necessary to feel about in the orbital tissue before dressing the case." ${ }^{2}$ Cox found pieces of glass as large as a square inch imbedded into the orbit. "Eyelids were cut into literal fringes and in addition to removal of the eyeball one often had to hunt to find material to reconstruct a set of lids." ${ }^{2}$ In many cases the eyes were completely destroyed. Cox went along the rows of patients, examining eyes and marking those who required operations. He then placed linen tags on his patients listing their name, address, injury, treatment and future needs. ${ }^{2}$

Cox performed 75 enucleations and five double enucleations in four days, all under chloroform anaesthesia. ${ }^{2}$ He did not record the total number of patients he treated. Cox would find the sclerotic attachments for the muscles, cut the tendons and the optic nerve, and remove everything under

Abbreviation: EENT, eye, ear, nose and throat 


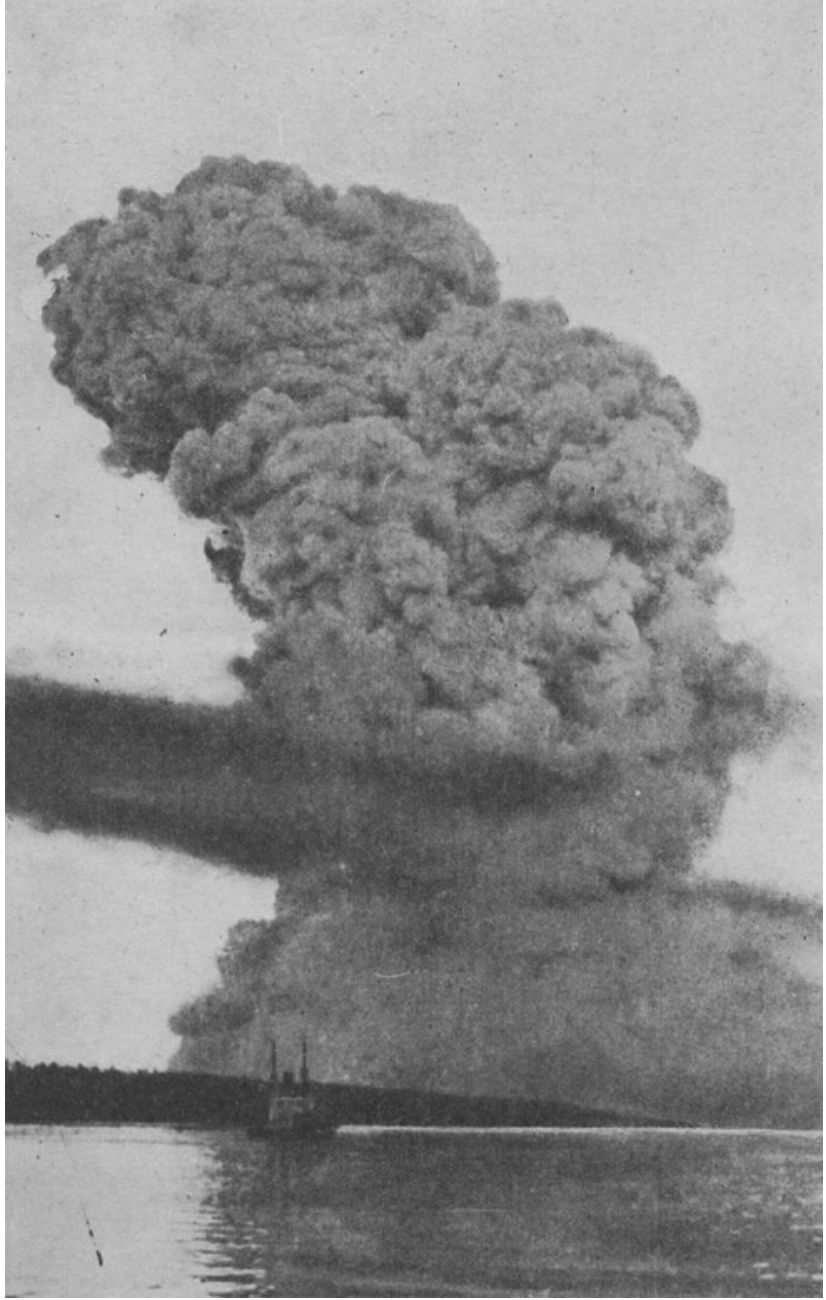

Figure 1 Photograph of the Explosion cloud taken on 6 December 1917, $13 \mathrm{~km}$ away from Halifax. Printed with permission from PANS, Halifax Relief Commission collection, number 1976-166.106, N-2373.

Tenon's capsule. In many cases it was not possible to do a formal operation. Several corneal perforations had an associated prolapsed iris. He repaired these cases under topical cocaine anaesthesia by either reducing the edges of the iris or excising the prolapse. Foreign bodies removed from the orbit included glass, pottery, brick, mortar and nails. Lacerated lids were primarily repaired. Cox, as an EENT specialist treated several people with basal skull fractures, all of whom died, and, he was referred the severe facial lacerations. "Mouths were cut almost from ear to ear. In many cases they looked as if a tiger's claw had ripped down their faces." ${ }^{2}$

Trains from Boston and Montreal were delayed by snow storms in New Brunswick. ${ }^{78}$ On the fifth day, the train from Montreal arrived with Captain TF Tooke, an EENT specialist with the Canadian Army Medical Corps. ${ }^{9}$ Tooke found Cox in a small back room at the Camp Hill Hospital operating by the light of a single bulb. Cox had performed so many operations that his instruments would no longer cut. Most of the Camp Hill patients had already been treated by Cox, with only a few dozen unseen. ${ }^{2}$ Cox returned to New Glasgow and Tooke started triaging patients.

Tooke was taken aback by the state of the untreated injuries, "practically every face wound was septic; nay more, each was welling out with a copious purulent discharge while other

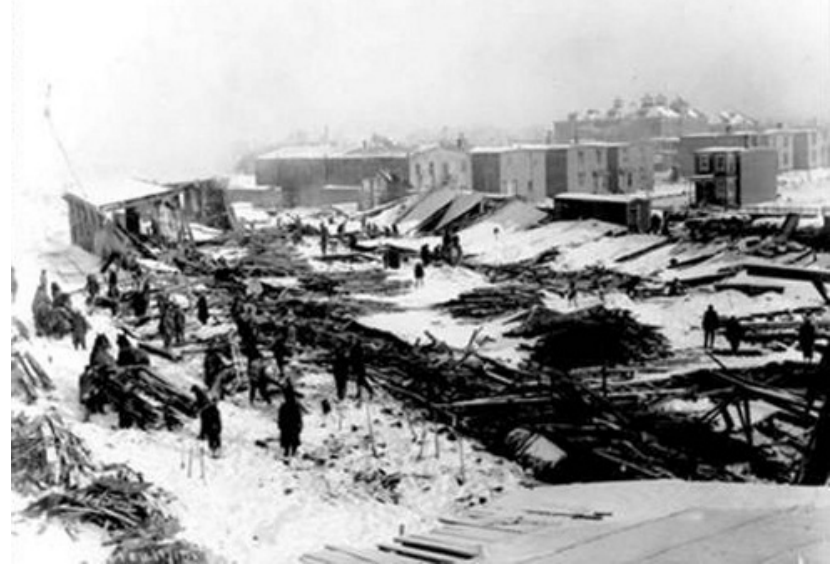

Figure 2 Collapsed buildings in the North End of Halifax, Nova Scotia, Canada. Printed with permission from PANS, Charles Vaughan collection, N-7036.

wounds appeared almost to be gangrenous."'9 Tooke performed 48 eye operations, 16 of which required enucleation. He asked Sergeant Wallace of the Army Service Corps to take note of each patient's name, case and treatment, and published the details of his experience in the April 1918 edition of the Canadian Medical Association Journal (table 1). ${ }^{9}$

Table 1 Records of a subgroup of patients treated by Captain TF Tooke during the Halifax explosion, published in the Canadian Medical Association Journal ${ }^{p}$

\begin{tabular}{|c|c|c|}
\hline $\begin{array}{l}\text { Number } \\
\text { of cases }\end{array}$ & $s$ Nature of injury & Treatment \\
\hline 7 & Lacerated lids/necrotic wounds & Lids sutured. Dressing \\
\hline 12 & $\begin{array}{l}\text { Perforated cornea, prolapsed } \\
\text { iris/incarcerated iris }\end{array}$ & $\begin{array}{l}\text { Edges of iris freed, presenting iris } \\
\text { excised, iridectomy. Flap of } \\
\text { conjunctiva sutured over wound }\end{array}$ \\
\hline 6 & $\begin{array}{l}\text { Corneal abrasions and } \\
\text { perforations without inclusion } \\
\text { of iris/ciliary body (single or } \\
\text { multiple) }\end{array}$ & Atropine and Dressing. \\
\hline 12 & $\begin{array}{l}\text { Complete destruction of eye } \\
\text { ball/eyeball torn to shreds/ } \\
\text { eyeball collapsed }\end{array}$ & Enucleated \\
\hline 1 & Perforated sclera & $\begin{array}{l}\text { Conjunctiva sutured over wound. } \\
\text { Double dressing }\end{array}$ \\
\hline 1 & Perforated cornea & $\begin{array}{l}\text { Iridectomy, argyrols, atropine } \\
\text { and bandage }\end{array}$ \\
\hline 4 & $\begin{array}{l}\text { Perforated cornea/sclera, } \\
\text { prolapsed ciliary body/ } \\
\text { incarcerated ciliary body. } \\
\text { Prolapsed vitreous }\end{array}$ & $\begin{array}{l}\text { Excised prolapse, sutured } \\
\text { conjunctiva over wound. } \\
\text { Atropine, argyrols, double } \\
\text { dressing }\end{array}$ \\
\hline 3 & $\begin{array}{l}\text { Long perforated wound } \\
\text { extending from cornea to sclera } \\
\text { and ciliary body/prolapse of } \\
\text { ciliary body }\end{array}$ & Enucleated \\
\hline 1 & $\begin{array}{l}\text { Multiple corneal wounds with } \\
\text { hyphaema }\end{array}$ & Atropine and dressing \\
\hline 1 & $\begin{array}{l}\text { V-shaped wound of cornea } \\
\text { with deposits of lymph about } \\
\text { edges. Hyphaema }\end{array}$ & $\begin{array}{l}\text { Edges of wound freed. Atropine } \\
\text { and dressing }\end{array}$ \\
\hline 1 & $\begin{array}{l}\text { Scleral wound over ciliary } \\
\text { body. Ciliary body and vitreous } \\
\text { presenting }\end{array}$ & Enucleated \\
\hline 2 & $\begin{array}{l}\text { Perforated cornea. Traumatic } \\
\text { cataract }\end{array}$ & Atropine and dressing \\
\hline 1 & $\begin{array}{l}\text { Organs cannot be } \\
\text { distinguished }\end{array}$ & Enucleated \\
\hline
\end{tabular}

Patients with both eyes injured and/or with several types of injuries are listed in more than one category. 
Tooke enucleated eyes that were completely destroyed. Those with multiple perforating injuries extending into the sclera and involving ciliary body were also enucleated. Several cases had prolapsed ciliary body or presenting vitreous, which were excised. One patient's eye was enucleated by the force of the explosion. Many cases were treated conservatively in an attempt to preserve the eye, using atropine, argyrol as antiseptic and bandages. Tooke performed paediatric examinations under chloroform sedation. He freed incarcerated irises, performed iridectomies, and sutured sclerae, conjunctivae and lids. ${ }^{9}$

In 1917, oculists, as ophthalmologists of the day were called, would sometimes insert an artificial globe after enucleation. They would fill Tenon's capsule with a glass, gold or paraffin sphere, or would insert a piece of fat excised from another part of the body. The tendons of the recti muscles were then sutured together and covered by the margins of Tenon's capsule and the conjunctiva. ${ }^{10}$

Tooke performed one or two "Lister operations", in which he separated the extra-ocular muscles, eviscerated the contents of the globe and excised most of the sclera, leaving only a "small curtain" of sclera around the optic nerve. ${ }^{9}$ The residual sclera was thought to prevent spread of infection behind the orbit. In only one of his cases did infection ensue, a virtue Tooke attributed to the "Queen's Laundry Bar" he used to wash his hands and the argyrol antiseptic used in wounds. He refused to use rubber gloves when performing delicate eye operations. ${ }^{9}$

Requests for further help were sent. Mathers, a local oculist, wired the Massachusetts Eye and Ear Infirmary requesting them to send two specialists, MacKenzie and Goodall, with four nurses. ${ }^{6}$ Two others, JW Stirling from Montreal and D Harvey from Providence, Rhode Island, also came to help treat the injured. ${ }^{6}$

The overall medical response to the Halifax Explosion included 322 medical doctors, 52 from the Halifax area and 96 from the United States. ${ }^{6}$ In total, 12 oculists treated 592 people with eye injuries and performed 249 enucleations. Sixteen people had both eyes enucleated. In comparison, 223 bone fractures were repaired and 25 amputations performed at the local hospitals. ${ }^{6}$ The disproportionate number of eye injuries occurred because of the delay between the fire onboard the Mont Blanc and the explosion itself. Haligonians looked through double-paned storm windows at the fire and the glass shattered into their faces with the explosion. In all, 9000 people were injured in the explosion and over 2000 died. $^{67}$

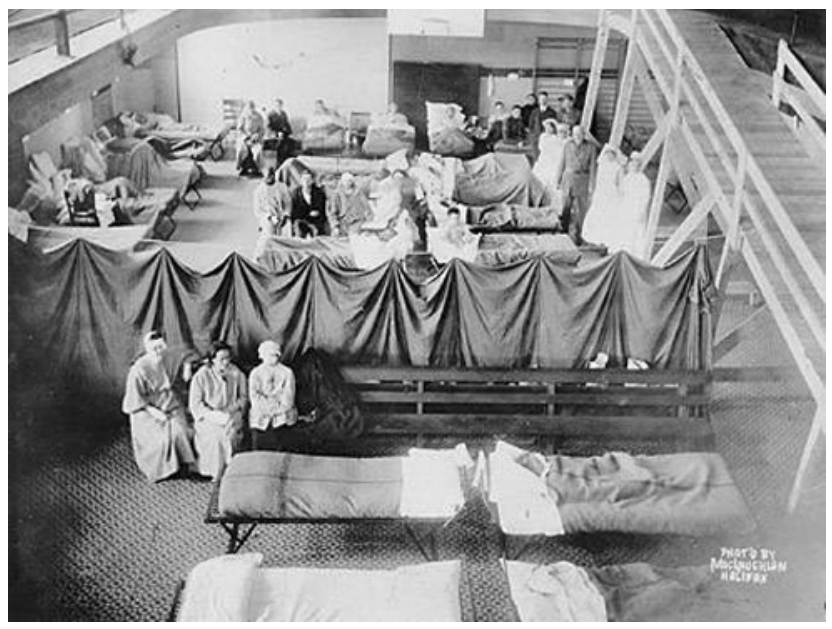

Figure 3 Emergency relief hospital in the YMCA, Halifax, Nova Scotia. Printed with permission from PANS, Lola Henry collection, number 1979$237.8, \mathrm{~N}-7024$
By the tenth day, most patients had been treated, transferred home or to units in neighbouring cities of Truro, Windsor, New Glasgow and Sydney. Tooke returned to Montreal. ${ }^{9}$

\section{RELIEF}

On 8 December 1917, over 50 people gathered at the City Club in downtown Halifax, including Prime Minister Sir Robert Borden. ${ }^{7}$ They coordinated relief work and formed 12 committees. The Medical Relief Committee was responsible for setting up emergency medical stations, assessing needs, allocating medical supplies and coordinating medical relief efforts. There were 2500 patients overloading the local hospitals, and eight temporary hospitals were set up at local schools and clubs (fig 3). ${ }^{3}$

Sir Frederick Fraser, superintendent of the Halifax School for the Blind, organised a series of clinics for patients with eye injuries. ${ }^{6}$ He was also instrumental in organising the Blind Relief Fund through the Halifax Relief Committee, and in January 1918 he published a newspaper request asking for information from those with eye injuries (fig 4). ${ }^{11}$ Hundreds of letters were received. Patients described the method of their eye injuries, treatments received, costs incurred and expected visual outcome. Several patients reported that it was necessary to remove the injured eye to save the sight of their other eye. ${ }^{11}$

Patients were visited by a nurse for regular eye dressing changes. Fraser contacted oculists for details regarding each case and the costs of treatment. An enucleation by Mathers was reported to cost $\$ 65$, equivalent to US\$899 ( $£ 465.5$, $€ 682.3$ ) today. ${ }^{11}$ All medical bills, and expenditure for eye glasses and artificial eyes were covered by the Halifax Relief Commission. ${ }^{3}$

Artificial eyes available at the time included the Shell eye, a thin shallow glass cup, and the Reform eye, a more modern Snellen design that was thicker and deeper. ${ }^{10}$ The prostheses were removed every night and were replaced every year. Plastic artificial eyes had not yet been developed. Tooke incorrectly extrapolated from his cases that 500 people would require an artificial eye and that 150 would be left blinded by the explosion. ${ }^{9}$ By June 1918, 145 glass artificial eyes, custom made in Boston, had been supplied by the Halifax Relief Commission and 40 persons were reported to be totally blind. Eight children, ranging from 6 to 14 years of age, were totally blinded. Two children, a 13-year-old and a 7-year-old, were partially blinded. These children were sponsored by the Halifax Relief Commission to board at the Halifax School for the Blind, where they were educated and trained in trades. Forty-eight children in total were reported to have suffered from eye injuries. ${ }^{6}$

The visually impaired were classified according to acuity and given a pension funded by the Halifax Relief Commission through the Canadian National Institute for the Blind. ${ }^{12}$ The Canadian National Institute for the Blind, established in 1918, kept yearly records of services rendered, and activities and addresses of those receiving pensions. In 1954, they recorded 21 survivors receiving pensions ranging from US\$37-94 per month, an equivalent of US\$183-618 (£94.76-320, $€ 138.9-469$ ) today. $^{12}$ Services provided through the School for the Blind, included teaching in Braille, basketry, typing and cooking for women, and leather work and piano tuning for men. The Massachusetts Halifax Relief Committee, organised to provide furniture and to redevelop public health services in Halifax, provided \$25000 to blind relief. ${ }^{13}$ These funds were used to supply special equipment for blind households, including kitchen cabinets, bread mixers, washing machines and sewing machines. The estimated total medical cost of the disaster was $\$ 4$ million, equivalent to US\$55 (£28, €41) million today. ${ }^{6}$ 


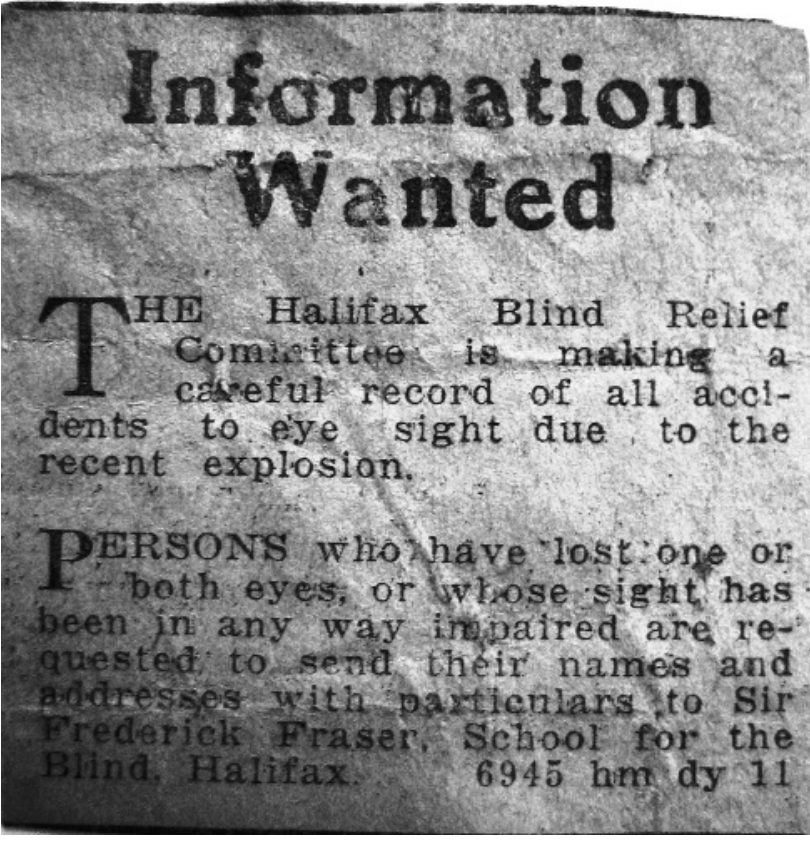

Figure 4 Saturday, 5 Jan 1918: The Evening Mail. Halifax Relief Committee requests information from persons who sustained eye injuries in the Explosion. Printed with permission from PANS RG 14, Series S, Vol 17, 3.

\section{REFLECTIONS}

In his 1918 article in the Canadian Medical Association Journal, Tooke reflects on whether too many eyes were removed during the relief efforts. ${ }^{9}$ Tooke reports an enucleation rate of $33 \%$, and it is estimated that $42 \%$ of all injured eyes were enucleated by oculists at the surrounding hospitals and private clinics. ${ }^{6}$ However, many of the urgent cases were addressed by local specialists before Tooke arrived in Halifax, and many reported that the eyes they enucleated were totally destroyed. ${ }^{\circ}$

In 1917, sympathetic ophthalmia was the feared complication of penetrating eye injuries and a common indication for enucleation. It is a bilateral granulomatous panuveitis that occurs after the uvea of one eye is subjected to a penetrating injury. In the early 1900s, the cause of the inflammatory response in the uninjured eye was theorised to be due to metastasis of toxins through the blood from pathogenic bacteria contaminating the injured eye. ${ }^{10}$ Remnant glass fragments were also known to cause significant inflammation, and it was impossible in some cases to ensure that all particles were removed. ${ }^{9}$ As Cox described, "it was as if the ball had been laid open and then stuffed with pieces of glass-or sometimes crockery, brick, splinters, and on palpation they would clink." ${ }^{\prime 2}$

Tooke decided to repair through operation several eyes with presenting iris, ciliary body or vitreous instead of enucleation, removing the incarcerated tissue and repairing the wound. ${ }^{9} \mathrm{He}$ was more likely to try and save the eye if the patient had both eyes injured. ${ }^{9}$ He admits to worrying that these patients could have sympathetic trouble due to inclusion of the ciliary body or retention of small glass particles in the uveal tract. ${ }^{9}$

Sympathetic ophthalmia is now thought to be an immunogenic response triggered by exposed uveal antigens. The older literature generally has found the incidence after a perforating injury to be approximately $2 \%{ }^{14}$ In the Franco-Prussian War (1870-1), the prevalence of sympathetic ophthalmia was $55.5 \%$ among the Germans and 50\% among the French. ${ }^{15}$ As a result of improvements in modern surgical and medical treatment, it has become uncommon, occurring today in $1 / 500$ penetrating eye injuries. ${ }^{16}$

The modern management of perforating eye injury has greatly improved, although the prognosis for good recovery of vision is often guarded with major injuries. However, the potential for regaining useful vision justifies an attempt at repair whenever feasible. Primary enucleation should be considered only in the event of total disruption of the globe. This includes those patients in whom large amounts of intraocular contents have been extruded or who have large scleral lacerations or ruptures that are completely irreparable. Initial repair permits evaluation of the total ocular status in the immediate postoperative period, with possible secondary enucleation at a later date. Several primary enucleation cases described by the Halifax Explosion oculists met these modern criteria (table 1). The severity and the overwhelming number of eye injuries sustained during the Halifax Explosion made it impossible for the 12 oculists to perform lengthy eye-saving procedures. In many cases enucleation was the only option.

Detailed historical records from the Halifax Explosion provide insight into a traumatic event with unique ophthalmological importance and demonstrate how penetrating eye injuries were treated in 1917.

\section{Authors' affiliations}

Chryssa N McAlister, Faculty of Medicine, Dalhousie University, Halifax, Nova Scotia, Canada

T Jock Murray, Charles E Maxner, Department of Medicine (Neurology), Dalhousie University, Halifax, Nova Scotia, Canada

Hesham Lakosha, Department of Ophthalmology and Visual Sciences,

Dalhousie University, Halifax, Nova Scotia, Canada

Competing interests: None.

\section{REFERENCES}

1 McCall S. Telegram: Governor of Massachusetts. PANS, MG36, Series C, 113.2.

2 Cox G. PANS, MG1, Vol 2606, 169.

3 MacMechan Fond. Medical Relief Committee of the Halifax Disaster. MGI, Vol, 2124:1-20.

4 Halifax stunned by blast thought germans had attacked from sea and air simultaneously. Boston Post 7 Dec 1917

5 Ruffman A, Howell C. Ground zero: a reassessment of the 1917 explosion in the Halifax harbour. Halifax: Nimbus Publishing Limited \& Goorsebrook research Institute, St Mary's University, 1994:276-7.

6 Fraser Harris Report The medical relief work of the Halifax disaster. PANS, MG36, series C, 119 .

7 Kitz JF. Shattered city: the Halifax Explosion and the road to recovery. Halifax: Nimbus Publishing, 1989:173-95.

8 MacDonald LM. Curse of the narrows: the Halifax Explosion of 1917. Toronto: Harper Collins Publishers, 2004

9 Tooke TF. An experience through the Halifax disaster. Can Med Assoc J 1918;8:308-20.

10 May CH. Disease of the eye. New York: William Wood and Company, 1914:88-91.

11 Halifax Relief Committee. PANS, RG14, series S, Vol. 17, 3

12 CNIB Halifax Relief Commission Eye Cases. PANS, MG36, series C, Vol. 28.

13 Massachusetts Halifax Relief Committee. PANS, MG36, series C, vol. 84.

14 Duke-Elder S, Perkins ES. Sympathetic ophthalmitis. In Diseases of the uveal tract. St Louis: Mosby, 1966:558.

15 Fuchs E. Uber Ophthalmia sympathica. Graefe's Arch Clin Exp Ophthalmol 1909;70:465.

16 Lubin JR, Albert DM, Weinstein M. Sixty-five years of sympathetic ophthalmia. A clinicopathologic review of 105 cases (1913-1978). Ophthalmology 1980;87:109-21 